\title{
A Meta-Analysis of Constructivist Learning Approach on Learners' Academic Achievements, Retention and Attitudes
}

\author{
Çetin Semerci ${ }^{1}$, Veli Batdi ${ }^{2}$ \\ ${ }^{1}$ Bartın University, Education Faculty, Bartın, Turkey \\ ${ }^{2}$ Ministry of Education, Elazığ, Turkey \\ Correspondence: Veli Batdi, Ministry of Education, 23200, Elazığ, Turkey
}

Received: January 26, 2015

Accepted: February 10, 2015 Online Published: February 25, 2015

doi:10.11114/jets.v3i2.644

URL: http://dx.doi.org/10.11114/jets.v3i2.644

\begin{abstract}
This study attempts to answer the question 'Does a Constructivist Learning Approach have any effect on learners' academic achievement, retention and attitude scores?' As a result of a systematic investigation of experimental studies carried out between 2002 and 2015 in national and international area, 324 (218 articles, 106 theses) studies were found. Pre-test-post-test and group comparison processes were applied to 28 of these experimental studies and these studies were more importantly included in the meta-analysis research. In statistical analyses, the classifications by Thalheimer and Cook (2002) were taken into consideration. The effect size of Constructivist Learning on academic achievement $_{(\mathrm{ES}: 1.0753)}$, retention ${ }_{(\mathrm{ES}: 0.9249)}$ and attitude ${ }_{(\mathrm{ES}: 0.4394)}$ were calculated considering the effect size. This result indicates that the effect sizes on academic achievement and retention are at a large level while on attitude is at a medium. It was concluded at the end of the research that a constructivist learning approach has a positive effect on learners' academic success, retention and attitude scores. In relation to the results, some recommendations were made for practitioners and further research.
\end{abstract}

Keywords: constructivist learning, traditional method, meta-analysis

\section{Introduction}

Until now, several different methods have been used for intellectual activities, such as knowledge reconstruction and problem solving through a learning process (Ar1 \& Bayram, 2011, p. 312). Constructivist learning, as one of the current methods commonly used in the instruction process (Olssen, 1996, p. 275), came about because of Kant's thoughts that learners are not passive information receivers. However, in today's context, constructivism was developed by J. Piaget and J. Dewey (Özden, 2006; as cited in Duman, 2007, p. 310). Constructivism has become a common learning theory, which is frequently used in the instruction process (Bulut, 2009, p. 8). Information is perceived and interpreted as a hypothesis and not as a reality (Schunk, 2011, p. 237). When recent innovations in the education system were examined, it can be pointed out that there are several promising instructional approaches; however they are not sufficient enough to support the teaching-learning processes of daily life. Moreover, educational innovation arises as a result of how learners learn and how teachers teach. If we consider the fact that an individual search for understanding eases the complexity of learning, and that individuals construct their learning through reflection upon interactions and experience (Brooks \& Brooks, 1993, p. 4), the value of a constructivist approach, which is based on real life learning experiences, is apparent.

A constructivist approach suggests that learners construct knowledge through real life experiences as a cognitive activity, rather than simply learning from abstract concepts (Butler, Miller, Lee, \& Pierce, 2001, p. 20). One of the views on this approach, based on individual experience (Kim, 2005, p. 8), belongs to Brooks and Brooks (1993, p. 8). Their observations point to five basic principles: “1) Posing problems of emerging relevance, 2) Building lessons around primary concepts, 3) Seeking and valuing learners' points of view, 4) Adapting instruction according to learners' points of view and 5) Assessing learner learning in the context of daily teaching." These characteristics of a constructivist approach underline that learners should be actively involved in all instructional processes from start to finish. Also, it is emphasized that lessons should be organised in accordance with learner needs and interests to build up a motivational learning environment, rather than the focus being on the teacher (Akyol, 2011, p. 10; Özmen \& Y1ldırım, 2005, p. 65). Such a constructivist curriculum is considered to have a greater effect on learner success.

In the current education system, it seems that teachers do not consider constructivism as an efficient teaching-learning 
approach within the curriculum. In fact, teachers can be recommended to adopt some efficient and practicable methods to support this approach (Bayrak, 2008, p. 11). At this point, Yeşilyurt (2013, p. 3) emphasized that learners should collaborate with teachers through the process of a constructivist learning approach, such as defining attainment, forming content, teaching-learning and evaluating. Meanwhile, the duties of the teacher need to be clarified. The teacher, under the constructivist approach, should build up a meaningful learning environment to enhance learners' learning from all aspects (Ercan, 2009, p. 26). Hence, learners should be encouraged to adopt a self-directed independent learning approach under the supervision of their teachers (İnan, 2009, p. 29). Due to the fact that learning is based on reconstructing knowledge and sharing explanations, reasons, conjectures and intuitions (Sheppard, 2004, p. 51), learners should shape information blocks to learn by themselves. The modern era requires that individuals discover, interpret the information and shape unique knowledge blocks (Yıldırım \& Şimşek, 1993, p. 9). In other words, constructivist learning involves two main phases. Firstly, the individual constructs the knowledge on values and experience and secondly, knowledge is shaped according to the characteristics of that individual and the efficacy of the process (Bulut, 2009, p. 9). From this point, it is understood that the characteristics and experience of the individual have a significant role in the learning process.

Constructivism enables learners to actively participate in the learning process by acquiring capabilities, such as independent learning and self evaluation. From this aspect, the constructivist approach involves reconstructing knowledge, rather than accepting a piece of information as a given. Thus, the piece of knowledge constructed by the learner can be defined as being more permanent. Consequently, the permanency of knowledge in the constructivist approach can also be interpreted as having a positive impact on learners' success. Hence, this study was conducted to research this positive effect of the constructivist approach on learners' success.

\section{Method}

In this research, the meta-analysis method was used in order to find out the effects of constructivist learning on the success rate. Meta-analysis, referring to the analysis of analyses, can be defined as a method of statistical analysis of a large collection of results from individual studies for the purpose of integrating the findings (Glass, 1976, p. 3). The meta-analysis method was proposed as an alternative to traditional literature reviews. However, meta-analysis studies are more flexible and common. In addition to this, meta-analyses include quantitative techniques, such as opinion questionnaires, correlational studies, experimental and quasi experimental studies and regression analyses to integrate research results, while literature reviews include qualitative techniques (Kaşarc1, 2013, p. 33).

\subsection{Data Collection}

Meta-analysis is known as a method of integration and a critical review of findings and results from different studies (Akgöz, Ercan, \& Kan, 2004, p. 107). Research studies from 2002-2015 in national and international area on the effects of constructivist learning on the success rate were analysed in this study, based on the meta-analysis method. In this context, both in English and Turkish, key words such as "constructivist learning", " $<<$ constructivist learning and academic success $>>$ ", "constructivist learning environment", $<<$ constructivist approach and academic success $>>$ were searched from ProQuest Dissertations and Theses (PQDT), Taylor \& Francis Online, Ebscohost-Eric, ScienceDirect, National Thesis Centre of the Council of Higher Education and Google Scholar.

The search process was renewed at certain intervals for recent studies, and hence, 324 related studies were found. Only articles and theses were included in the study. Some of the studies found were not included in this study due to their lack of statistical measurements. Pre-test-post-test and group comparison processes were carried out in 28 of 324 studies (218 articles, 106 theses), which were examined for the current research.

Twenty eight studies (10 articles, 18 theses) were included in the meta-analysis. The following criteria were used for the selection of studies to be included in this study: 1) Studies that used a constructivist approach and pre-test-post-test control procedures, 2) Studies that investigated the effect of a constructivist approach on learners' academic success, 3) Studies that reported sample size (n), arithmetic mean (X) and standard deviation (sd) values of experiment and control groups to calculate effect sizes, 4) Studies conducted in national or international area and 5) Studies conducted between 2002-2015.

\subsection{Encoding Method}

The studies which were chosen according to the criteria of inclusion were encoded as general enough to allow the inclusion of all studies, and at the same time specific enough to allow differentiation (Camnalbur, 2008, p. 51). Data for this study was coded in two parts. Firstly, study identity and study content were coded with sub-categories as author names, the year of the study, the type of the publication, the name of the lesson, the level of education, conceptual subject and length of instruction. Then, in the second section, statistical information necessary to conduct meta-analysis, such as sample sizes, arithmetic means and standard deviations were extracted. In addition, dependent variables in this 
study were the effect sizes, calculated based on the achievement, retention and attitude scores in each study included in the meta-analysis of this study. Effect sizes were described as standard values for each study that use different measurement tools (Bernard et al., 2004, p. 63).

\subsection{Study Characteristics}

The study characteristics, which are known as independent variables of the meta-analysis, are coded to evaluate the relationship between effect sizes, and these characteristics are used in data analysis (Tarım, 2003). The study characteristics for the current study were identified as follows: education levels of the learners, lessons in which the studies were conducted, study span, volume of the study, standard deviation and mean values of the samples in the study.

\subsection{Data Analysis}

In this study, treatment effectiveness meta-analysis was used for the analysis of the data. This method is used for group differences when the arithmetical mean values of the dependent variables of each study included in meta-analysis were not obtained using the same scale (Camnalbur \& Erdoğan, 2008). In order to integrate the statistical findings of different studies, these findings are initially required to be measured as effect sizes in this method. While the effect coefficients were measured for effect size values of arithmetic means in this study, classifications by Thalheimer and Cook (2002) were used $(-0.15<$ Cohen's $d<0.15$ negligible; $0.15<$ Cohen's $d<0.40$ small; $0.40<$ Cohen's $d<0.75$ medium; $0.75<$ Cohen's $d<1.10$ large; $1.10<$ Cohen's $d<1.45$ very large and $1.45<$ Cohen's $d$ huge).

On the other hand, in order to carry out the calculations for meta-analysis, Microsoft Excel 2010 Office programs, CMA (Comprehensive Meta-Analysis) statistics package and MetaWin programs were used. In the study, the significance level was taken as 0.5. Following the classifications carried out using statistics of the current study, meta-analysis was used with a fixed effect model and a random effect model. Moreover, the coding reliability was calculated to increase the reliability of the research outcomes in this meta-analytic research. All the reviewed research was examined by another reader who is academically at an advanced level. Following the examination, two raters' coding result was noted down to the final evaluation form of this article. The consistency of the raters' evaluations in the form was examined according to the inter-rater reliability calculation formula [consensus /(consensus + dissensus) x 100] (Miles and Huberman, 1994) and the outcome of reliability was found to be $100 \%$.

\section{Results}

A total of 28 studies were used to examine their statistical findings, revealing arithmetic means and standard deviations of the use of a constructivist approach in instructional processes. With this purpose, 10 articles, 12 master theses and 6 doctoral theses were included in the meta-analysis. Following the literature review, 26 studies on academic achievement, 9 on retention and 13 on attitude related to Constructivist Approach were reached.

The statistics displaying education levels, subject areas, instruction spans, publication types, province, country, years, frequency and the percentage index of these studies are presented in Table 1. According to the statistical data in Table 1, in terms of education levels most of these studies were conducted at secondary school level (50\%) and at undergraduate level (32.14\%), followed by high school level (14.29\%) and primary school level (3.57\%). On the other hand, 17 studies involved Science and Technology (60.71\%), 6 studies involved Maths (21.43\%) and 5 studies involved Social Studies (17.86\%). In terms of study length, 11 studies (39.28\%) were mainly conducted in 2-4 weeks, $14.29 \%$ in 5-6 and 7-8 weeks, $17.86 \%$ in 9-18 weeks. By the way, 4 of the studies (14.29\%) were signified as unspecified, because of the fact that they were evaluated with course spans instead of weekly evaluation.

Table 1. Frequency and Percentage Index for Categorical Independent Variables of the Studies Involving Data Concerning the Effect of a Constructivist Approach in an Instructional Environment on Academic Success Score

\begin{tabular}{|c|c|c|c|c|c|c|c|c|}
\hline Variable & $(f)$ & $(\%)$ & \multirow{2}{*}{\multicolumn{3}{|c|}{$\begin{array}{l}\text { Variable } \\
\text { Publication Type }\end{array}$}} & $(f)$ & \multicolumn{2}{|c|}{$(\%)$} \\
\hline Education Level & & & & & & & & \\
\hline Primary & 1 & 3.57 & Article & & & 10 & \multicolumn{2}{|c|}{35.71} \\
\hline Secondary & 14 & 50 & Master's Thesis & & & 12 & \multicolumn{2}{|c|}{42.86} \\
\hline High School & 4 & 14.29 & Doctoral dissertatio & & & 6 & \multicolumn{2}{|c|}{21.43} \\
\hline Undergraduate & 9 & 32.14 & \multicolumn{6}{|c|}{ Study Province, Country, Year, Frequency and Percentage Values } \\
\hline Subjects & & & Province, Country & $(f)$ & $(\%)$ & Year & $(f)$ & $(\%)$ \\
\hline Science & 17 & 60.71 & Ankara & 10 & 35.71 & $2002 / 4$ & $1-1$ & 7.14 \\
\hline Maths & 6 & 21.43 & Balıkesir-Trabzon & $1+1$ & 7.14 & 2005 & 2 & 7.14 \\
\hline Social Studies & 5 & 17.86 & Denizli & 2 & 7.14 & 2007 & 5 & 17.86 \\
\hline \multicolumn{3}{|c|}{ Study Practice length (Week) } & Diyarbakır & 3 & 10.71 & 2008 & 1 & 3.57 \\
\hline $2-4$ & 11 & 39.28 & Erzurum & 3 & 10.71 & 2009 & 5 & 17.86 \\
\hline $5-6$ & 4 & 14.29 & Eskişehir & 2 & 7.14 & 2010 & 4 & 14.29 \\
\hline $7-8$ & 4 & 14.29 & İstanbul & 2 & 7.14 & 2011 & 3 & 10.71 \\
\hline $9-18$ & 5 & 17.86 & Kars-Adana & $1+1$ & 7.14 & 2012 & 3 & 10.71 \\
\hline Unspecified & 4 & 14.29 & USA-Korea & $1+1$ & 7.14 & 2014 & 3 & 10.71 \\
\hline
\end{tabular}


In terms of where studies took place, studies included in the meta-analysis were conducted in 10 different provinces and 3 different countries (Turkey, USA, and Korea). From this aspect, Ankara is the place where most of the studies (N:10, $35.71 \%$ ) were conducted. In terms of when studies were carried out, they were mostly conducted in 2007/9 (17.86\%) and $2010(14.29 \%)$. In addition to the national studies, there are also studies (Brooks, 2010; Kim, 2005) conducted in different countries (USA and Korea) related to the same subject.

\subsection{Analysis of Academic Success Results of the Studies Included in the Meta-AnalysisRecruitment}

Table 2 displays the homogeneity values, mean effect sizes and confidence intervals in effect models of the studies included in meta-analysis concerning the use of constructivist learning approach in the academic environment. As is shown in Table 2, the results of the meta-analysis based on the fixed effects model indicated that the standard deviation was 0.048 ; the upper limit of $95 \%$ confidence interval was 0.9624 , the lower limit was 0.7635 and the mean effect size was $\mathrm{ES}=0.8629$. Z-test calculations revealed 18.041. At the end of the homogeneity test, the Q-statistical value was calculated to be 196.7105 .

Table 2. Homogeneity Values, Mean Effect Sizes and Confidence Intervals in Effect Models of the Studies Included in Meta-Analysis

\begin{tabular}{|c|c|c|c|c|c|c|}
\hline \multirow{2}{*}{ Model Type } & \multirow{2}{*}{$\mathrm{n}$} & \multirow{2}{*}{$\mathrm{Z}$} & \multirow{2}{*}{ Q } & \multirow{2}{*}{$\mathrm{ES}$} & \multicolumn{2}{|c|}{$\% 95$ Confidence Intervals } \\
\hline & & & & & Lower Limit & Upper Limit \\
\hline FEM & 26 & 18.041 & 196.7105 & 0.8629 & 0.7635 & 0.9624 \\
\hline REM & 26 & 7.768 & 28.0492 & 1.0753 & 0.7891 & 1.3615 \\
\hline
\end{tabular}

FEM: Fixed Effects Model $\quad$ REM: Random Effects Model Rosenthal's Method: 3698.7

As found in the chi-square $\left(\chi^{2}\right)$ table, 25 degrees of freedom at a $95 \%$ significance level was 37.652. As a result of the homogeneity test, the Q-statistic was calculated as 196.7105 according to the fixed effects model values of 26 studies. From this point, the hypothesis of homogeneity of the distribution of the effect sizes of the studies was rejected, since the Q-statistic was bigger than the critical value of $\chi 2$. In other words, the distribution of the effect sizes of the studies was heterogeneous in terms of the fixed effects model.

Due to the fact that the results of the homogeneity test were higher than the variance that could be expected, the variance of the distribution was calculated according to the random effects model. The results of the meta-analysis, conducted based on the random effects model, indicated that the use of a constructivist approach in instruction has a positive effect on learning; the standard deviation was 0.138 ; the upper limit of $95 \%$ confidence interval was 1.3615 , the lower limit was 0.7891 and the mean effect size was $E S=1.0753$. The mean effect sizes of the studies, ranging from 0.1826 and 3.3996, were accepted to be huge, very large, large, medium and small in the classifications by Thalheimer and Cook (2002).

\subsection{Analysis of the Retention Scores of the Studies Included in the Meta-Analysis}

In this part of the study, the number of the samples, standard deviations and arithmetic means were analyzed in terms of general characteristics and effect sizes of 9 ( 1 article, 6 master's, 2 doctorate theses) studies investigating the efficacy of the constructivist approach on learners' retention scores (Table 3). The results of the meta-analysis based on the fixed effects model indicated that the retention scores were higher in constructivist based instruction than in traditional teaching methods; the standard deviation was 0.080; the upper limit of 95\% confidence interval was 1.0031 , the lower limit was 0.6320 and the mean effect size was 0.8176 . The mean effect sizes calculated were accepted to be large in the classifications by both Thalheimer and Cook (2002). Z-test calculations were revealed to be statistically significant at 10.259 .

Table 3. Homogeneity Values, Mean Effect Sizes and Confidence Intervals in Effect Model Retention Scores of the Studies Included in Meta-Analysis

\begin{tabular}{lcccccc}
\hline \multirow{2}{*}{ Model Type } & $\mathrm{n}$ & $\mathrm{Z}$ & $\mathrm{Q}$ & $\mathrm{ES}$ & \multicolumn{2}{c}{ 95 Confidence Interval } \\
& & & & & Lower Limit & Upper Limit \\
\hline FEM & 9 & 10.259 & 39.5604 & 0.8176 & 0.6320 & 1.0031 \\
REM & 9 & 4.978 & 7.3194 & 0.9249 & 0.4951 & 1.3548 \\
\hline
\end{tabular}

Rosenthal's Method: 675.5

As a result of the homogeneity test, the Q-statistic was calculated as 39.5604. As found on the $\chi 2$ table, 8 degrees of freedom at $95 \%$ significance level was 15.507. A Q-statistical value of 39.5604 was found to exceed the critical value of $\chi 2$ distribution at 8 degrees of freedom $\left(\chi 2_{(0.95)}=15.507\right)$. These values indicated that the distribution of the effect sizes of 
the studies were heterogeneous in terms of the fixed effects model. For this reason, it was decided to compare the results of analyses using the random effect size model. As a result, through analyses based on the random effects model, illusions caused by the heterogeneous sample can be eliminated.

The results of the analyses conducted according to the random effects model indicate that a constructivist approach is more effective than traditional teaching methods in terms of attitude scores with a standard deviation of 0.186; an upper limit of 1.3548 , a lower limit of 0.4951 for $95 \%$ confidence interval and a mean effect size of 0.9249 . The effect size value obtained was considered to have a large effect in terms of the classification by Thalheimer and Cook (2002). Following $\mathrm{z}$-test calculations that conducted to have a statistical significance, the $\mathrm{z}$ value was found to be 4.978 . The result of $\mathrm{p}=0.50259$ value shows that there is no statistical significance of the analysis.

\subsection{Analysis of Attitude Scores Results of the Studies Included in the Meta-Analysis}

In 13 studies in which the learning environments based on a constructivist approach were compared to learners' attitude scores in a traditional teaching environment, the experimental group consisted of 504 learners and the control group consisted of 481 learners. In order to define the study content, information such as the educational levels of the participants, lessons in which the studies were conducted, the length and year of the study, type of publishing and frequency and percentage statistics of province variables were specified in Table 4.

Table 4. Frequency and Percentage Index for Categorical Independent Variables of the Studies Involving Data Concerning the Effect of a Constructivist Approach in an Instructional Environment on Attitude Scores

\begin{tabular}{|c|c|c|c|c|c|c|c|c|}
\hline Variable & $(f)$ & $(\%)$ & \multicolumn{3}{|c|}{ Variable } & $(f)$ & \multicolumn{2}{|c|}{$(\%)$} \\
\hline \multicolumn{3}{|l|}{ Education Level } & \multicolumn{6}{|c|}{ Publication Type } \\
\hline Primary & 1 & 7.69 & \multicolumn{3}{|l|}{ Article } & 4 & \multicolumn{2}{|c|}{30.77} \\
\hline Secondary & 7 & 53.85 & \multicolumn{3}{|c|}{ Master's Thesis } & 6 & \multicolumn{2}{|c|}{46.15} \\
\hline High school & 2 & 15.39 & \multicolumn{3}{|c|}{ Doctoral dissertation } & 3 & \multicolumn{2}{|c|}{23.08} \\
\hline Undergraduate & 3 & 23.08 & \multicolumn{6}{|c|}{ Study Province, Year, Frequency and Percentage Values } \\
\hline Subjects & & & Year & $(f)$ & $(\%)$ & Province & $(f)$ & $(\%)$ \\
\hline Science & 6 & 46.15 & 2004 & 1 & 7.69 & Ankara & 4 & 30.77 \\
\hline Maths & 5 & 38.46 & 2005 & 1 & 7.69 & Balıkesir & 1 & 7.69 \\
\hline Social Studies & 2 & 15.38 & 2007 & 3 & 23.08 & Denizli & 1 & 7.69 \\
\hline \multicolumn{3}{|c|}{ Practice Length (Week) } & 2008 & 1 & 7.69 & Diyarbakır & 3 & 23.08 \\
\hline $2-4$ & 5 & 38.46 & 2009 & 3 & 23.08 & Erzurum & 2 & 15.38 \\
\hline $5-6$ & 4 & 30.77 & 2010 & 2 & 15.38 & Eskişehir & 1 & 7.69 \\
\hline $7-8$ & 2 & 15.38 & 2011 & 1 & 7.69 & Kocaeli & 1 & 7.69 \\
\hline $9-18$ & 1 & 7.69 & 2012 & 1 & 7.69 & & & \\
\hline Unspecified & 1 & 7.69 & & & & & & \\
\hline
\end{tabular}

The homogeneity values, mean effect sizes and confidence intervals in effect model attitude scores of the studies included in meta-analysis were presented in Table 5. In this context, the results of the meta-analysis conducted based on the fixed effects model indicates that standard error was 0.066; the upper limit of $95 \%$ confidence interval was 0.6037 , the lower limit was 0.3153 and the mean effect size was ES=0.4595. It is possible to say that the attitude scores of learners using a constructivist approach were higher than the scores achieved using a traditional teaching method. The mean effect size calculated as 0.4595 was accepted to be medium in the classifications by Thalheimer and Cook (2002). After the calculations of z-test conducted to have a statistical significance, the value of $\mathrm{z}$ was found to be 6.976 .

Table 5. Homogeneity Values, Mean Effect Sizes and Confidence Intervals in Effect Model Attitude Scores of the Studies Included in Meta-Analysis

\begin{tabular}{lcccccc}
\hline \multirow{2}{*}{ Model Type } & \multirow{2}{*}{$\mathrm{n}$} & $\mathrm{Z}$ & $\mathrm{Q}$ & \multirow{2}{*}{$\mathrm{ES}$} & \multicolumn{2}{c}{ \% 95 Confidence Interval } \\
& & & & & Lower Limit & Upper Limit \\
\hline FEM & 13 & 6.976 & 89.7840 & 0.4595 & 0.3153 & 0.6037 \\
REM & 13 & 2.362 & 13.1951 & 0.4394 & 0.0346 & 0.8443 \\
\hline
\end{tabular}

Rosenthal's Method: 194.9

As a result of the homogeneity test, the Q-statistic is calculated as 89.7840 . As found on the $\chi 2$ table, 12 degrees of freedom at 95\% significance level was 21.026. A Q-statistical value of 89.7840 was found to exceed the critical value of $\chi 2$ distribution at 12 degrees of freedom $\left(\chi 2_{(0.95)}=21.026\right)$. These values indicated that the distribution of the effect sizes of the studies was heterogeneous in terms of the fixed effects model. For this reason, it was decided to compare the results of 
analyses using the random effects size model.

The results of the analyses conducted according to the random effects model indicate that the constructivist approach is more effective than traditional teaching methods in terms of attitude scores with a standard deviation of 0.186; an upper limit of 0.8443 , a lower limit of 0.0346 for $95 \%$ confidence interval and a mean effect size of 0.4394 . The effect size value obtained is considered to have a medium effect in terms of the classification by Thalheimer and Cook (2002). After z-test calculations carried out to result in a statistical significance, the value of $\mathrm{z}$ was calculated to be 2.362 .

In meta-analytic research, studies resulting in null effect sizes are required to remove the statistical significance from the findings of the study.This is referred to as the Fail-safe Number $\left(N_{\mathrm{FS}}\right)$ (Rosenthal, 1979, cited in Thornton \& Lee, 2000, p. 212). In this study, the value of $N_{\mathrm{FS}}$ regarding the effect of constructivist learning on academic success was calculated as being 3698.7, on retention as 675.5 and on attitude as 194.9. If the specified number of studies were included in the meta-analysis, the effect size of constructivist learning on academic success, retention and attitude would decrease to 0.001 . When considering that studies included in the meta-analysis were chosen in terms of the inclusion criteria following the literature review, it can be claimed that it is not possible to obtain any more studies, and the results of the analysis are therefore reliable.

\section{Discussion}

In this study, it was concluded that the frequent use of a constructive learning approach in different lessons and subjects makes a significant contribution to learners' academic achievement, retention and attitude scores. Quantitative research carried out from 2002-2015 reveals the effectiveness of constructive learning on academic achievement, retention and attitude. Twenty-eight control group-experimental studies related to this study are included in meta-analysis.

When these 28 studies, which included academic achievement, retention and attitude scores are taken into consideration, 5 research studies $(17.86 \%$ ) were carried out in $2007 / 9$ in terms of years. When considering the provinces, $35.71 \%$ of the studies were carried out in Ankara and in terms of education level $50 \%$ of these studies were carried out at secondary school level. Moreover $60.71 \%$ of the studies were carried out in Science lessons regarding subject fields, $39.28 \%$ of the research studies were carried out in $2-4$ weeks in terms of the study practice length and $42.86 \%$ of these studies involved masters' degrees considering publication type.

Using a random effects size model in terms of academic achievement with CMA Statistics and MetaWin programmes, the mean effect size was calculated as 1.0753. It shows that a constructivist learning approach is more effective than a traditional learning method. According to Thalheimer and Cook (2002), it can be interpreted as having a high effect. The findings of these studies prove that a constructivist learning approach is more successful than traditional teaching methods in terms of learners' academic success. These findings are consistent with other national research studies, which were carried out in different years and excluded from the analysis (Şişman, 2007; Aydın, 2008).

According to the other research study question, the effectiveness of a constructivist learning approach on learners' retention level was examined. As mentioned in the findings, it was discovered that the use of a constructivist learning approach in a learning environment increases the retention scores of learners. However, it is inferred in the study which examines retention and a constructivist approach that there is no significant change on the success of both groups (Anadaç, 2007). The reason for this is possibly that a retention test was done right after the study (Dinçer \& Güçlï, 2013). In general terms, the results show that a constructivist approach led to greater academic success than traditional teaching methods in terms of learners' retention scores. Therefore, it is possible to say that the learning environment in which the constructivist approach is applied has a positive effect on learners' recall levels.

Evaluating the effectiveness of using the constructivist approach in a learning environment on learners' attitudes is the last research question. Using a random effects size model, the mean effect size was calculated as ES=0.4394, when mean effect sizes of 13 studies including the learners' attitude scores were measured in the meta-analytic study. According to the classification by Thalheimer and Cook (2002), this size is accepted as medium when the effect size is examined. According to the results of analysis, the use of a constructivist approach has a positive effect on the experimental group. On the other hand, when the attitude scores of some studies based on the data gathered from this research are examined, there is no difference between the experimental and control groups (Baytok, 2007; Karaduman, 2005; Gül \& Yeşilyurt, 2011; Anadaç, 2007). In other words, teaching environments in which the constructivist approach is applied are not effective in developing a positive attitude by learners towards the lesson, or even if there is a little difference between the experimental and control groups. It is shown that the attitudes of learners towards the lessons are statistically the same (Akın, 2007). The reason for these results may be that attitudes don't change in a short period of time.

According to the results of studies included in meta-analysis, it was found that the use of a constructivist approach in a learning environment is most effective in learners' academic success, retention and attitude scores. On the other hand, it 
was emphasized that learners develop positive attitudes towards the related lesson by using this approach. Thus, it can be suggested that the use of this type of application, which makes a major contribution to both learners' academic achievement, retention and attitude scores, should be promoted. Although both national and international studies are included in the research analysis, there are not so many international studies and thus it is a necessity to carry out many more international studies. This situation reveals the fact that the analysis of international studies related to the constructivist approach is necessary. On the other hand, using complete data sets is of great importance for meta-analysis, due to the fact that the missing statistical data $(\bar{X}, \mathrm{n}, \mathrm{SS}$, etc.) is difficult for researchers to analyze. Finally, it was discovered in this study that meta-analytic research was rarely conducted for statistical integration. Thus, it can be meaningful to suggest further research is carried out to focus on meta-analysis.

\section{References}

(The references marked with an asterisk $(*)$ are used in meta-analysis study.)

Akgöz, S., Ercan, İ., \& Kan, İ. (2004). Meta-analizi [Meta-analysis]. Journal of Uludă̆ University Faculty of Medicine, $30,107-112$

*Akın, M. F. (2007). Özdeşlik konusunun öğretiminde yapılandırmacı öğrenme yaklaşımının öğrenme ürünlerine etkileri. [The effects constructivist approach on learning products in teaching the subject of identity]. (Unpublished master's thesis), Dicle University, Diyarbakır.

*Akyol, S. (2011). Sosyal yapılandırmacı öğrenme ortamı tasarımının öğrenenlerin akademik başarılarına ve ögrenmenin kalıcllı̆gına etkisi (ilköğretim 5. Sinıf fen ve teknoloji dersi). [The effects of social constructivist learning environment design on academic achievement and learning retention of learners (science and technology course at the 5th grade of primary school)]. (Unpublished master's thesis), Yıldız Teknik University, İstanbul.

*Anadaç, K. (2007). Gözden geçirme stratejisi ile desteklenmiş yapılandırmacı öğrenme yaklaşımının 5E modelinin ögrencilerin basınç konusundaki erişilerine, bilgilerinin kalıcılı̆̆ına ve tutumlarına etkisi. [The effects of 5E model of Constructivist Learning Approach, which is supported by reviewing strategy in teaching the subject of pressure over the students' achievements, attitudes and the permanence of knowledge]. (Unpublished master's thesis), Dicle University, Diyarbakır.

*Arı, E., \& Bayram, H. (2012). Yapılandırmacı yaklaşıma dayalı kimya laboratuar uygulamalarının öğrencilerin başarısına, bilimsel süreç becerilerine ve laboratuar performanslarına etkisi. [The impact of constructivism based general chemistry laboratory practices on students' the achievement, scientific process skills and laboratory performance]. Western Anatolia Journal of Educational Sciences (WAJES), 3, 1-18.

Arı, E., \& Bayram, H. (2011). Yapılandırmacı yaklaşım ve öğrenme stillerinin laboratuvar uygulamalarında başarı ve bilimsel süreç becerileri üzerine etkisi. [The influence of constructivist approach and learning styles on achievement and science process skills in the laboratory]. Elementary Education Online, 10, 311-324.

Aydın, S. (2008). Illköğretim 6. sınıf fen ve teknoloji dersi kuvvet ve hareket ünitesinin sosyal yapılandırmacı ögrenme yaklaşımı çerçevesinde ögretimi. [Teaching of force and motion unit of grade 6 science and technology lesson under social constructivism perspective]. (Unpublished master's thesis), Balıkesir University, Balıkesir.

*Aytaş, A. (2014). Yapılandırmacı öğrenme yaklaşımının öğrencilerin İngilizce konuşma becerisine etkisinin belirlenmesi. [Determining the effect of constructivist learning approach on students' English speaking skills]. (Unpublished master's thesis), Ankara University, Ankara.

*Bayrak, N. (2008). Yapılandırmacı öğrenme yaklaşımının beş aşamalı modeline uygun olarak geliştirilen ders yazılımı ve çalışma yapraklarının öğrencilerin başarısına, öğrenilen bilgilerin kalıcılı̆̆ına ve ögrrencilerin fen bilgisi dersine yönelik tutumlarina etkisinin incelenmesi. [Examining the effect of course software and worksheet improved in accordance with five-stage model of constructivist learning approach on students' achievement, retention of knowledge, and attitudes towards science courses]. (Unpublished master's thesis), AtatürK University, Erzurum.

*Baytok, H. (2007). Yapılandırmacı öğrenme kuramına dayalı öğretimin ilköğretim 7. sınıf basınç konusunda öğrenci başarısı ve tutumuna etkisi. [The effect of constructivist teaching approach on seventh grade prımary school students' achievement in the subject of pressure and attitude toward science]. (Unpublished master's thesis), Balıkesir University, Balıkesir.

Bernard, R. M., Abrami, P. C., Lou, Y., Borokhovski, E., Wade, A., \& Wozney, L. (2004). How does distance education compare with classroom instruction? A meta-analysis of the empirical literature. Review of Educational Research, 74, 349-361. 
*Bilen, K., \& Köse, S. (2012).Yapılandırmacı öğrenme teorisine dayalı etkili bir strateji: tahmin-gözlem-açıklama (TGA) "Bitkilerde büyüme ve gelişme". [An effective strategy based on constructivist theory: Prediction-Observation-Explanation (POE) "Growth and development in plant"]. Pamukkale University Journal of Education Faculty, 31, 121-134.

*Bogar, Y., Kalender, S., \& Sarikaya, M. (2012). The effects of constructive learning method on students' academic achievement, retention of knowledge, gender and attitudes towards science course in "matter of structure and characteristics" unit. Procedia - Social and Behavioral Sciences 46, 1766 - 1770.

*Brooks, J. (2010). The effectiveness of constructivist science instructional methods on middle school students' student achievement and motivation. (Unpublished doctoral dissertation). Walden University, United States.

Brooks, J. G., \& Brooks, M. G. (1993). In search of understanding the case for constructivist classrooms. Alexandria, Virginia: ASCD Publications.

*Bulut, M. (2009). İşbirliğine dayalı yapılandırmacı öğrenme ortamlarında kullanılan bilgisayar cebir sistemlerinin matematiksel düşünme, ögrenci başarısina ve tutumuna etkisi. [The effect of computer algebra systems in the constructivist approach based cooperative learning environment on mathematical thinking and academic performance of students]. (Unpublished doctoral dissertation), Gazi University, Ankara.

Buttler, F. M., Miller, S. P., Lee, K., \& Pierce, T. (2001). Teaching mathematics to student with mild-to-moderate mental reterdation, A Reviw of the Literature, Mental Reterdation, 39, 20-31. http://dx.doi.org/10.1352/0047-6765(2001)039<0020:TMTSWM>2.0.CO;2

Camnalbur, M. (2008). Bilgisayar destekli öğretimin etkililiği üzerine bir meta analiz çalı̧̧ması. [A meta-analysis for the effectiveness of computer based education]. (Unpublished master's thesis), Marmara University, İstanbul.

Camnalbur, M., \& Erdoğan, Y. (2008). Bilgisayar destekli öğretimin etkililiği üzerine bir meta analiz çalışması: Türkiye örneği. [A meta-analysis on the effectiveness of computer-assisted instruction: Turkey sample]. Educational Sciences: Theory \& Practice, 8, 497-505.

*Çiftçi, E. (2010). Illköğretim 6. sınıf matematik dersi geometri öğrenme alanında yapılandırmacı öğrenme yaklaşımına dayalı ögretimin ögrenci başarısina ve tutumuna etkisi. [The effect of teaching based on constructivist learning approach to student success and attitude in the field of learning geometry in primary education grade 6]. (Unpublished master's thesis), Gazi University, Ankara.

*Demircioğlu, G., \& Çağatay, G. (2014). The effect of laboratory activities based on 5e model of constructivist approach on 9th grade students' understanding of solution chemistry. Procedia - Social and Behavioral Sciences, 116, 3120-3124. http://dx.doi.org/10.1016/j.sbspro.2014.01.719

Dinçer, S., \& Güçlü, M. (2013). Fen bilgisi eğitiminde bilgisayar destekli simülasyon kullanımının etkililiği ve yönelimler: Bir meta-analiz çalışması. [Effectiveness of using simulation in computer aided learning and new trends in science education: A meta-analysis study article title in English language]. International Journal of Human Sciences, 10, 49-66.

Duman, B. (2007). Eğitimde çağdaş yaklaşımlar. [Contemporary approaches in education]. Gürbüz Ocak, (Ed.), Teaching principles and methods. (p. 283-391), (1. edition), Ankara: Pegem A Publication.

*Ercan, S. (2009). Yapılandırmacı öğrenme yaklaşımı 5E öğretim modelinin madde döngüleri konusunun öğretilmesine etkisi. [The effect of constructivist approach 5E learning model on teaching material cycle]. (Unpublished master's thesis), Gazi University, Ankara.

Glass, G. V. (1976). Primary secondary and meta-analysis of research. Educational Researcher, 5, 3-8. http://dx.doi.org/10.3102/0013189X005010003

*Gül, Ş., \& Yeşilyurt, S. (2011).Yapılandırmacı öğrenme yaklaşımına dayalı bilgisayar destekli öğretimin öğrencilerin tutumlarl ve başarlarl üzerine etkisi. [The effect of computer assisted instruction based constructivist learning approach on students' attitudes and achievements]. The journal of Necatibey Education Faculty, Electronic Science and Mathematics Education, 5, 94-115.

*İnan, C. (2009). Yapılandırmacı öğrenme yaklaşımının öğrencilerin trigonometriyi öğrenme düzeylerine ve matematiğe yönelik tutumlarına etkisi. [Effect of constructivist learning approach on the students' trigonometry learning levels and attitudes towards math]. (Unpublished doctoral dissertation), Dicle University, Diyarbakır.

*Kaplan, A., Tortumlu, N., \& Kaplan, N. (2010). Matris konusunun öğretiminde yapılandırmacı kuramının öğrenci başarısına etkisi. [Effect to student success of constructivist theory in the teaching of matrix]. Erzincan University Institute of Science Journal, 2, 153-167. 
*Karaduman, H. (2005). Sosyal bilgiler dersinde yapılandırmacı öğrenme ilkelerine göre hazırlanan ögretim materyallerinin ögrencilerin derse ilişkin tutumlarına, başarllarına ve hatırlama düzeylerine etkisi. [The effect of teaching materials prepared in accordance with the principles of constructivist learning on students' attitudes, success and level of recall in the course of social studies]. (Unpublished master's thesis), Anadolu University, Eskişehir.

Kaşarcı, İ. (2013). Proje tabanl ögrrenme yaklaşımının ögrencilerin akademik başarı ve tutumlarına etkisi: bir meta-analiz çallşması. [The effect of Project-based learning approach on students' academic achievement and attitude: a meta-analysis study]. (Unpublished master's thesis), Eskişehir Osmangazi University, Eskişehir.

*Kim, J. S. (2005). The effects of a constructivist teaching approach on student academic achievement, self-concept, and learning strategies. Asia Pacific Education Review 6(1), 7-19. http://dx.doi.org/10.1007/BF03024963

*Kirişçioğlu, S. (2007). İlköğretim 7. sınıf fen bilgisi dersi "basınç" konusunun yapılandırmacı öğrenme yaklaşımına dayalı ögretiminin akademik başarlya etkisi. [The effect of constructivist learning approach based instruction in elementary school seventh (7th) class science lesson "pressure" subject on academic achievement]. (Unpublished master's thesis), Pamukkale University, Denizli.

*Koç, G. (2002). Yapılandırmacı öğrenme yaklaşımının duyuşsal ve bilişsel öğrenme ürünlerine etkisi. [The effect of constructivist learning approach on affective and cognitive learning outcomes]. (Unpublished doctoral dissertation), Hacettepe University, Ankara.

*Mant, S. (2007). Desen ĕgitiminde yapılandırmacı öğrenme uygulamalarının etkililiği (Dumlupınar Üniversitesi Örneği). [The effectiveness of constructivist learning applications in design education]. (Unpublished doctoral dissertation), Anadolu University, Eskişehir.

Miles, M. B., \& Huberman, A. M. (1994). Qualitative data analysis: An expanded sourcebook. Thousand Oaks, California: Sage.

Olssen, M. (1996). Radical constructivism and its failings: Anti-realism and individualism. British Journal of Educational Studies, 44, 275-295. http://dx.doi.org/10.1080/00071005.1996.9974075

*Orhan, A. T., \& Bozkurt, O. (2009).Yapılandırmacı yaklaşıma göre fotosentez konusunun öğretiminin incelenmesi. [Examining the instruction of photosynthesis subject by constructivist approach]. Kastamonu Education Journal, 17, 905-918.

Özmen, H., \& Yıldırım, N. (2005). Çalışma yapraklarının öğrenci başarısına etkisi: asitler ve bazlar örneği. [The effect of worksheet on students' academic achievement: sample of acids and bases]. The Journal of Science Education, 2, 125-143.

*Sağlıker, Ş. (2009). Yapılandırmacı öğrenme kuramına dayalı olarak kütle çekim kanunu konusunda hazırlanan ders yazllıminin ögrencilerin akademik başarısına etkisi. [The effects of multimedia courseware based on constructive learning theory on students academic achievement in the teaching the topic gravitation theory]. (Unpublished master's thesis), Çukurova University, Adana.

*Sarıkaya, M., Güven, E., Göksu, V., \& Aka, E. İ. (2010). Yapılandırmacı yaklaşımın öğrencilerin akademik başarı ve bilgilerinin kalıcılığı üzerine etkisi. [The impact of constructivist approach on students' academic achievement and retention of knowledge]. Elementary Education Online, 9, 413-423.

Schunk, D. H. (2011). Learning Theories: An educational perspective (Translator Ed.: M. Şahin). Ankara: Nobel Publication.

*Seçken, N., \& Ural Alşan, E. (2011). The effect of constructivist approach on students' understanding of the concepts related to hydrolysis. Procedia Social and Behavioral Sciences, 15, 235-240. http://dx.doi.org/10.1016/j.sbspro.2011.03.079

Sheppard, L. (2004). Towards a constructivist pedagogy for year 12 mathematics. Australian Senior Mathematics Journal 22, 50-58.

Şişman, M. (2007). İlköğretim 8. sınıf matematik dersi çarpanlara ayırma ve özdeşlikler konusunun yapılandırmacı ögrenme yaklaşımına uygun olarak ögretiminin öğrenci başarısına etkisi. [The effect of teaching the issue of factorization and identity with the help of constructivist learning approach on students' academic achievement in Primary 8th grade mathematics lesson]. (Unpublished master's thesis), Gazi University, İzmir.

Tarım, K. (2003). Kubaşık öğrenme yönteminin matematik öğretimindeki etkinliği ve kubaşık ögrenme yöntemine ilişkin bir meta analiz çalışması. [The efficacy of cooperative learning method in mathematics teaching and a meta-analysis of cooperative learning method]. (Unpublished doctoral dissertation). Çukurova University, Adana. 
Thalheimer, W., \& Cook, S. (2002). How to calculate effect sizes from published research articles: A simplified $\begin{array}{lccc}\text { methodology. } & \text { Retrieved } & \text { January } & 10, \\ \text { http://www.bwgriffin.com/gsu/courses/edur9131/content/Effect_Sizes_pdf5.pdf }\end{array}$

Thornton, A., \& Lee, P. (2000). Publication bias in meta-analysis: its causes and consequences. Journal of Clinical Epidemiology 53, 207-216. http://dx.doi.org/10.1016/S0895-4356(99)00161-4

*Yenice, E. (2014). Yapılandırmacı yaklaşımın 7e öğrenme modelinin 8. sınıf Fen ve Teknoloji dersi "mitoz ve mayoz bölünme" konusunda öğrencilerin akademik başarllarına etkisinin incelenmesi. (Unpublished master's thesis), Kafkas University, Kars.

Yeşilyurt, E. (2013). Öğretmen adaylarının öğrenim gördüğü ortamların yapılandırmacı öğrenme açısından değerlendirilmesi (Bir eğitim fakültesi örneği). [Assessment of learning environments of pre-service teachers in terms of constructivist approach (An education faculty sample)]. Gazi University Journal of Gazi Education Faculty, 33, 1-29.

Yıldırım, A., \& Şimsek, H. (1993). Nitel araştırma yöntemleri. [Qualitative research methods] Ankara: Seçkin Publication.

*Yurdakul, Y. (2004). Yapılandırmacı öğrenme yaklaşımının öğrenenlerin problem çözme becerilerine, biliş̧̈tesi farkindalık ve derse yönelik tutum düzeylerine etkisi ile ögrenme sürecine katkllarl. [The effect of constructivist approach on learners' problem solving skills, metacognitive awareness and attitudes towards the course and contributions to learning process]. (Unpublished doctoral dissertation). Hacettepe University, Ankara.

\section{(c) B B}

This work is licensed under a Creative Commons Attribution 3.0 License. 